\title{
Semiotic Study of Japanese Views on Sea in Hayao Miyazaki's Ponyo on the Cliff by the Sea
}

\author{
Fajria Noviana* $^{*}$ \\ Faculty of Humanities, Diponegoro University, Semarang - Indonesia
}

\begin{abstract}
This paper is a semiotic study of Hayao Miyazaki's anime Ponyo on the Cliff by the Sea. The purpose of this study is to reveal the Japanese views on sea in the anime. This anime was selected because it is considered to represents the modern Japanese narrative related to the sea, and regarding that anime as a popular literary work is generally more acceptable at various age levels of audience than classical literary works. The results of semiotic reading on this anime are five Japanese views on sea, which are 1) sea as a source of life; 2) sea as a source of prosperity; 3) sea as a source of strength or energy; 4) sea as a source of beliefs; and 5) sea as a source of beauty.
\end{abstract}

Keywords: sea; Japanese views; anime; semiotic

\section{Introduction}

Greenberg stated that animation can be defined as a "text" bearing distinctive representational traits vis a vis cinema. Furthermore, he also said that the basic meaning of animation is its ability to convey concepts, rather than objects [1]. Thus, products such as anime, films, novels and other literary works can represent the culture of a nation.

This paper discusses the Japanese views on sea, which data taken from Hayao Miyazaki's anime Ponyo on the Cliff by the Sea [2]. Miyazaki is a director and co-founder of Studio Ghibli, a large Japanese animation film studio that has produced such anime as Spirited Away, My Neighbor Totoro, Howl's Moving Castle, etc. As a director whose works have become icons of Studio Ghibli, Miyazaki is considered to have an extraordinary contribution to contemporary pop culture by the international film community [3].

Schnellbacher stated that from anime we can see that apparently the sea as a narrative space features prominently in the genealogy of science fiction, from fantastic voyages in the Odyssey tradition to the adventure stories of the twenty first century [4]. Furthermore, according to Asai, water in some Miyazaki's anime become an important element in the transformation of life [5]. Meanwhile, this paper focused on Japanese views on sea in Miyazaki's anime Ponyo on the Cliff by the Sea, regarding that anime as a popular literary work is generally more acceptable at various age levels of audience than classical literary works.

To achieve this paper's purpose, the connotative semiotic approach [6] is used because what is conveyed in a literary work is often in the form of signs that must be interpreted. Connotative semiotics is based on denotative characteristics to obtain connotative meaning,

* Corresponding author: fajria.noviana@live.undip.ac.id 
meaning of language as a second model system and signs that appear do not have a direct meaning. This genre which was pioneered by Barthes, aside from being applicable in literature, can also be applied in various society fields [7].

\section{Method}

This research design uses qualitative methods. Data collected in the form of events, objects and figures that related to the sea in the research corpus, which is Miyazaki's anime Ponyo on the Cliff by the Sea. Data collection using observation and record technique, while the data analysis uses connotative semiotic design.

\section{Results and Discussion}

The anime Ponyo on the Cliff by the Sea that was released in Japan on July 19, 2008, influenced by Andersen's The Little Mermaid. Since it has very much resembled of Japan, we can say that there is almost nothing in common with The Little Mermaid's story. The main character Ponyo, somehow reminds us about Chihiro or Sen, the main character of Miyazaki's Spirited Away. Even though both of them were little girls who acted as the main characters seemed like the only thing they had in common, both Ponyo and Chihiro has "from zero to hero" quality [8], through their own hero's journey.

The story centers upon the character of Ponyo, a goldfish princess who live in the sea. During a forbidden escapade to see the surface world, she encounters a human boy named Sosuke, who gives her the name Ponyo. According to Miyazaki, Ponyo's name is an onomatopoeia, based on his idea of what a "soft, squishy softness" sounds like when touched. Ponyo longs to become human, and as her friendship with Sosuke grows, she becomes more humanlike. Ponyo's father Fujimoto brings her back to their sea kingdom, but Ponyo's wish to live on the surface is so strong that she breaks free. And in the process, she unintentionally spills huge amount of Fujimoto's magic potion into the ocean causes a tsunami that endanger Sosuke's small town. The seaside small town where the story takes place is based on a contemporary Japanese small town along the Seto Inland Sea [5].

Based on anime Ponyo on the Cliff by the Sea, Japanese views on sea can be explained in several points as follows.

- Sea as a source of life

In this anime, we found a similarity with the book Kojiki (712 AD) and Nihonshoki (720 AD) about the creation of life. These books contain mythology of the origin of the formation of the island nation of Japan by the God Izanagi and Goddess Izanami [9], whilst Fujimoto creates ocean animals, particularly jellyfishes, in his vessel deep down in the sea with his magic potion and Ponyo's mother Gran Mamare producing all underwater life as the Mother of the Sea. We can see a lot of jellyfish in the beginning of the story, which reminding us to how Japanese archipelago looks like in the beginning of their creation as mentioned in Kojiki and Nihonshoki - floating like jellyfish.

- Sea as a source of prosperity

As a source of income for the residents of a small coastal town whose majority works as a fisherman, the sea where Ponyo lives has provided enough welfare for them, since there is no depiction of residents living in poverty. Besides, Fujimoto's vessel can be considered as a representation of Takarabune, or treasure ship in English, since it was a place where Fujimoto creates ocean animals that later can be fished by those fishermen on the surface. In Japanese mythology, Takarabune is a symbol of marital felicity, longevity, and good wishes, as well as turtles and cranes [10], that can be seen in this anime. 
- Sea as a source of strength or energy

Arising tsunami which caused by the spill of Fujimoto's magic potion when Ponyo tried to break free from her father's lock up, has drowned the small coastal town where Sosuke live. Even so, no townspeople were injured, even their houses remained intact. In addition, ships that had been swept by the tsunami waves into the middle of the sea were all still intact and can return to the dock, complete with its crews. Moreover, along with the tsunami, Ponyo's mother Gran Mamare helps rejuvenate the elderly women in Sunflower House nursing home, enabling them to walk again. As Miyazaki states that there's no point in portraying these natural disasters as evil events [11], we can clearly see his statement through the depiction of beneficial for the small town it wrecks, which with its ageing population and small coastal towns closely resembles the real Japan.

- Sea as a source of beliefs

As an island people whose livelihood and lines of communication were often associated with the sea, the Japanese unsurprisingly made the sea a locus of belief, practice, and art [10]. For example, to purify oneself by austerities, washing in pure or sea water, use of salt or fire, and avoiding polluting substances such as the dead, feces, and blood will add to one's store of kami [10], or gods and goddesses in English. Fujimoto showed this act of purifying when he came to the dryland to take Ponyo back from Sosuke. He sprayed sea water on the path in front of him, in his way to reach Sosuke's house. As the Mother of the Sea, Gran Mamare that was married to Fujimoto, who once a human, has hundreds of goldfish children. It depicts not only Izanagi and Izanami, but also the myriads of kami that Japanese has in their beliefs.

- Sea as a source of beauty

We can see how beautiful sea depicted in this anime, whether on the surface or in the depths of the sea, by the soothing picture of the sea and its coast, and the colorful underwater life. Besides, Gran Mamare who creates all underwater life is also a beautiful goddess, whether in form of a human or a mermaid. Undoubtfully, this is an example on how the Japanese made the sea a locus of belief, practice, and art [10].

\section{Conclusions}

As dryland inhabitant, human tends to assume that the sea has always been alien and dangerous, and those who have made it a second home have learned special skills and habits, for example fishermen and people who live near by the sea. Those assumptions that tend to be negative are generally based on human ignorance about the sea and how to tame its rage. But in reality, the sea can be a source of positive things in human life, as mentioned in previous discussion. Therefore, we should try to better understand what nature's needs and respect nature, because we live in it and depend very much on its generosity.

We would like to thank to Faculty of Humanities, Diponegoro University, for their support in the preparation of this paper, which was funded by DIPA funds for the 2020 fiscal year.

\section{References}

1. Swale, A. D. Anime Aesthetics: Japanese Animation and the "Post-Cinematic" Imagination. (Palgrave MacMillan, 2015).

2. Miyazaki, H. Ponyo on the Cliff by the Sea. (Toho, 2008).

3. Rustin, M. \& Rustin, M. Fantasy and Reality in Miyazaki’s Animated World. 
Psychoanal. Cult. Soc. 17, 169-184 (2012).

4. Schnellbacher, T. Has the Empire Sunk Yet? The Pacific in Japanese Science Fiction. Japanese Sci. Fict. 29, 382-396 (2002).

5. Asai, C. The Marginal World and the Role of Water in the Films of Hayao Miyazaki. Bull. Senri Kinlan Univ. 8, 10-15 (2011).

6. Ratna, N. K. Teori, Metode, dan Teknik Penelitian Sastra. (Pustaka Pelajar, 2008).

7. Zoest, A. van. Semiotika; Tentang Tanda, Cara Kerjanya, dan Apa yang Kita Lakukan Dengannya. (Yayasan Sumber Agung, 1993).

8. Noviana, F. Representasi Hero's Journey pada Tokoh Chihiro dalam Anime Spirited Away Karya Miyazaki Hayao. Izumi 8, 52 (2019).

9. Danandjaja, J. Folklor Jepang Dilihat dari Kacamata Indonesia. (PT Pustaka Utama Grafiti, 1997).

10. Ashkenazi, M. Handbook of Japanese Mythology. (ABC-CLIO, Inc., 2003).

11. Deloup, D. Japan's Fantasy Films Act as a Buffer Against the Reality of the Natural World. The Guardian (2011). 